\title{
Social network and institution-based strategy research
}

\author{
Sonja Opper ${ }^{1}$ (D)
}

Accepted: 27 October 2021/ Published online: 11 November 2021

(C) The Author(s) 2021

\begin{abstract}
Almost two decades ago, Asia Pacific Journal of Management, 19(2/3): 251-267 Peng (2002) called attention to the promise of institution-based strategy research. The puzzle was to explain differences in strategies around the globe. Building on the work accomplished so far, I ask: Can institution-based strategy succeed when embedded in inappropriate social networks? Institutions and networks are usually studied as separate phenomena, yet each also defines the capabilities of the other. Institutions shape social network contacts and structures because institutions define opportunities for affiliation and the relative value of distinct contacts and network structures. At the same time, social networks shape institutions and organizations' capabilities for institutional innovation. Thus, the social network in which a manager or organization is embedded can either amplify or counteract success in implementing institution-based strategy. After I review the co-constitutional nature of institutions and networks and discuss a number of sample studies using China as a productive research site, I sketch questions that need to be answered to more tightly integrate network behavior into institutional strategy research, and discuss four emerging areas of research into how network-strategy fit affects performance: (1) network fit to adaptive strategy, (2) network fit to change strategy, (3) institutional dynamics and network-strategy fit, and (4) institutional distance and network-strategy fit.
\end{abstract}

Keywords Institution-based research $\cdot$ Social network $\cdot$ Strategy $\cdot$ Method $\cdot$ China

The world is institutionally as diverse as it was three decades ago. Few of the transition and reform economies followed the seemingly superior "Washington consensus," and those that did realized rather mixed results. The World Bank, somewhat puzzled, concluded in its 2017 annual report, "policies that should be effective in generating positive development outcomes are often not adopted, are poorly implemented, or end up backfiring over time" (World Bank, 2017: 2). In contrast, some

Sonja Opper

Sonja.opper@unibocconi.it

1 Department of Management and Technology, Bocconi University, Milan, Italy 
of the countries that showed little ambition to embrace the principles of free market capitalism were economically more successful, with China standing out as a leader within this group (see Bruton et al., 2021 on China as an "aspirant economy"). Perhaps even more surprising, and certainly against predictions drawing on mainstream institutional theory (North, 1990; Williamson, 1985), global investors seemed to care little. Increasing shares of global foreign direct investment (FDI) have gone to transition and emerging economies with less than ideal institutional conditions. In 2020, in spite of the global influence of COVID restrictions, China even emerged as the top recipient of global FDI (UNCTAD, 2021).

This is the empirical background against which institution-based strategy research and the institutional-void literature have flourished. Both streams of research build on the insight that economic activity does "not grind to a halt because the government cannot or does not provide an adequate underpinning of law" (Dixit, 2004: 3). Speculation about an "institutional void" helped popularize the argument, highlighting the untapped business opportunities that are up for grabs for those who apply strategies that "fit emerging markets" (Khanna et al., 2005). In the search for fitting strategies, Peng pushed early and consistently for institution-based strategy research (Peng, 2002, 2003, 2014; Peng et al., 2009). In this framework, formal and informal institutions not only influence industry-based competition as well as firm specific resources and capabilities, but also directly determine the suitability of distinct strategies.

Peng's lead was productive and coincided with a broad search for the best strategies for emerging and transition economies, going beyond the initially dominant questions focusing on distinct growth strategies of the firm (Peng \& Heath, 1996; for a useful review of institution-based work in international strategy, see Hitt et al., 2016). Examples include the selection of market entry strategies (Meyer et al., 2009; Yiu \& Makino, 2002), identification of governance mechanisms (La Porta et al., 1998; La Porta et al., 1999), access to venture capital (Ahlstrom \& Bruton, 2006), R\&D strategies (Nandkumar \& Srikanth, 2016; Santangelo et al., 2016), supply chain management (Berman, 2011), and identification of effective corporate social responsibility strategies (El Ghoul et al., 2017; Ioannou \& Serafeim, 2012). A common approach in this broad set of empirical applications is to hold institutions constant when looking for the best organizational response. Regardless, foreign investors continue to realize smaller profit rates in institutionally less developed host countries than in their headquarters' locations, a fact highlighted by the vast literature on institutional distance in international business research (for reviews see Leung et al., 2005; Tihany et al., 2005).

So, what are we missing? One limitation is neglect of agency and governance (Carney et al., 2009). The empirical focus on strategy selection rather than implementation, however, is by choice and not by necessity. The institutional framework leaves room for analytical inclusion of the social microfoundations of strategy implementation. In particular, closer attention to social network agency, exploring ties connecting managers with intra-firm, inter-organizational, and community contacts, offers additional insights. Such a focus is promising for at least three reasons. First, there is growing evidence that recruitment of the right individuals - that is, individuals with networks that match their position and task-increases corporate 
performance, which supports the view "that research on social networks is more important to the study of strategy implementation than has heretofore been recognized" (Kleinbaum \& Stuart, 2014: 26; see also Burt \& Soda, 2021). Second, emergent organizational networks often follow from or mirror existing personal networks around strategic decision makers (Ma et al., 2009). Third, and related, the value of relational ties in the selection of business partners and realization of respective strategies tends to be amplified in countries with weak formal institutions and monitoring agencies (see also Boddewyn and Peng's (2021) reflections on the role of relational reciprocity in foreign market entry). In sum, there is good reason to explore the network embedding of strategy. The question I want to add to the agenda of institutional strategy research is: Can institution-based strategy succeed when embedded in inappropriate social networks? Or put differently: Does the social network in which a manager or organization is embedded amplify or counteract success of institution-based strategy?

Institution-based research has long emphasized the importance of relational ties-often seen as second-best solutions where formal institutions are weak or missing (Ahlstrom \& Bruton, 2006; Opper et al., 2017; Peng, 2002; Peng \& Heath, 1996; Peng \& Luo, 2000; Peng \& Zhou, 2005) and more recently as a critical factor influencing institutional innovation and the spread of new business practice (Chen \& Sun, 2019; Sarma \& Sun, 2017). Yet relational systems and reliance on informal institutions are not distinct features of management in emerging economies. Relational systems and social networks matter as much in countries with well-developed economic institutions (Bernstein, 1992; Ellickson, 1991; Macaulay, 1963) as in emerging and transition economies (Nee \& Opper, 2012). Critical differences reside in variable network contacts, structure, and purpose. To develop a deeper understanding of the interplay between social network agency and firm strategy, it therefore seems timely to shift from rather broad references to "relational systems" to a more nuanced and systematic structural analysis (Tasselli \& Kilduff, 2021 offer a recent review).

To sketch the benefits from a tighter incorporation of social network mechanisms into institution-based strategy research, I first break down the co-constitutional nature of institutions and social networks. This is to illustrate how certain institutional settings tend to cultivate distinct social networks, and differences in social network embeddedness influence institutional innovation and related diffusion processes. For strategists mindful of local institutions, this highlights the need to search for a productive network-strategy fit (see Fig. 1) in order to harvest the full performance effect of respective strategies. Four areas of research-(1) social network and adaptive strategy, (2) social network and change strategies, (3) institutional dynamics and network-strategy fit, and (4) institutional distance and network-strategy fit, each currently in its infancy-are identified that promise to develop a more precise understanding of how network-strategy fit affects performance.

Rather than providing an exhaustive literature review, I will select a number of studies that illustrate what can be gained from a more systematic social network foundation of institution-based strategy. The majority of these studies focus on the network embeddedness of entrepreneurs and managers of domestic firms in China. This empirical setting is both appealing and instructive, given the country's 


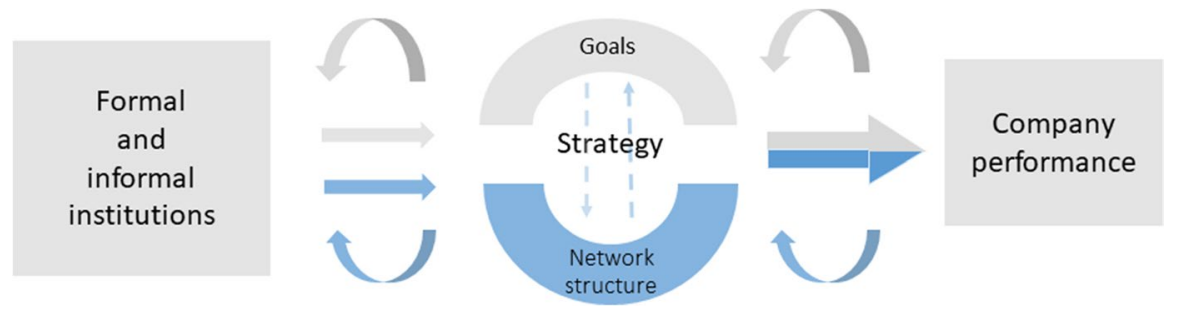

Fig. 1 The network-embeddedness of institution-based strategy. Note: For ease of presentation industrybased competition and firm-specific resources and capabilities are not presented, but assumed as independent factors influencing strategy (see Peng, 2014: 17). Gray areas denote the traditional causal chain assumed in institution-based strategy. Curved arrows signal feedback loops. Blue areas denote the suggested social micro-foundation of institution-based strategy and the required matching process to identify a productive network-strategy fit

particular interpretation of "rule by law" (Lubman, 2006) and its hybrid business system, which combines numerous market institutions with continuing state ownership and tight regulatory control, leaving abundant room for political ad-hoc interference in critical factor markets (Boisot \& Child, 1996; Lardy, 2019; Nee \& Opper, 2007). The country focus, however, should not distract from the general applicability of the network-strategy argument.

\section{Institutions shape networks}

Institutions and social networks are usually studied as separate phenomena. This reflects an established divide in the social science literature, with economists favoring the institutions-as-markets perspective (North, 1990; Williamson, 1985) and sociologists committed to the markets-as-networks perspective (Baker, 1984; Granovetter, 1985; White, 1981, 2002). Although both perspectives disagree with the stylized, neo-classical conception of the market as an anonymous forum of exchange (Demsetz, 1992), neither camp looks often for common ground or mutual dependencies. Although scholars in management have more freely employed, and also combined, both perspectives, there is little explicit discussion and even less tangible research exploring how one perspective informs the other (for exceptional discussions see, Beckert, 2010; Brass et al., 2004; Owen-Smith \& Powell, 2008; for a focus on Asia, see Peng \& Zhou, 2005).

Separate camps notwithstanding, the fact that social networks are readily coded as culturally distinct - with networks labeled as "guanxi" in China, "blat" in Russia, or "wasta" in the Middle East-mirrors a widely shared intuition that institutional forces, either at the national or regional level, shape social networks and agency. Moreover, social networks are instrumental in advancing institutional innovation and change, even though institutional change continues to be "much less understood... as stemming from the force of other social structures (i.e., social networks or cognitive frames)" (Beckert, 2010: 615) than stemming from state-guided top-down 
action (North, 1990; see Nee \& Opper, 2012: ch. 2 for a critique of the top-down perspective).

The literature on social networks combines two broad lines of research. The relational perspective focuses on the value of certain types of contacts (Lin, 2001). The premise is that performance and success depend on "who you know". A broad empirical literature singling out specific dyads as the object of study confirms the popularity of the approach beyond the boundaries of network research. The structural approach interprets the sum of interpersonal and inter-organizational contacts as network structures made up of contacts and associations, in which advantage depends on the position of individual actors (Burt, 1992, 2005). The two perspectives overlap and in both perspectives network attributes and capabilities areamong other factors-sculpted by institutions. Following convention and for the sake of clarity, I review network contacts and structure separately to describe how institutions define each simultaneously.

\section{Institutions and network contacts}

The social networks we build and maintain contain abundant kinds of contacts. In most networks there are childhood friends, classmates, friends we meet at college, neighbors, associates we meet in social clubs, and colleagues at work. Though every initial encounter looks like nothing but a serendipitous event ("what good fortune, that we met"), most of these encounters are at some level linked with institutional and organizational rules sorting individuals into cohorts and groups, making one encounter far more likely than another (see Feld, 1981, on the social organization of foci; Small, 2009, for detailed field work).

Administrative sorting into school districts channels students to better and worse schools, to schools in richer and poorer neighborhoods, and has children strike up their first friendships in life with fellow students from a similar socioeconomic background. University entrance exams sort the best students into elite universities and the weakest into community colleges. Upon graduation the process continues with initial employment contracts placing the best and most creative of their cohort with the best and most creative firms, where these graduates meet the best and most creative of past cohorts. Once ties are formed they are likely to lead to similar new ties through introduction of "friends of friends" and "colleagues of colleagues." Network qualities become self-reproducing (for emerging cliques among students see Festinger et al., 1950; for socializing relations in an MBA cohort see Kleinbaum, 2018; for homophilous association more generally, see McPherson et al., 2001; for homophilous association among China's political elite, see Opper et al., 2015). Clearly, institutions define the probabilities with which certain types and kinds of people are likely to meet others, as well as the likelihood of physical meetings turning into actual associations, depending on time spent together, frequency of meetings, and shared goals or tasks performed within certain institutional structures (Small \& Gose, 2020).

Institutions also define the specific value of relationships. Two mutually reinforcing mechanisms are critical. First, institutions define who is charged with 
gatekeeping functions and controls rights over resources of value to others. Such gatekeeping functions can be prescribed by national and regional laws and regulations defining access to distinct resources and information. They can also emerge from formal organizational rules or de-facto control rights within organizations. Second, institutions define who exactly depends on access to these same resources. In effect, both mechanisms jointly explain what type of specific "relationships and affiliations offer participants disparate types and amounts of capital" (Owen-Smith \& Powell, 2008: 604) and, consequently, which types of relations are valuable and worth pursuing and which are not.

To summarize, institutions shape network contacts and selection in at least three ways: (1) Institutions define the opportunities for interpersonal encounters; (2) Institutions define who controls which type of capital; and (3) Institutions define who depends on which type of capital. By derivation, on average there should be less variation within a sample of individual and organizational networks that are shaped by the same dominant institutional logic than across networks sampled from different institutional profiles. Because national and local institutions differ in the way they shape spheres of likely social encounters, gatekeepers, and dependencies, productive or valuable network contacts are likely to look different in different settings. It is useful to note, however, that none of the above rules out or even impedes individual agency, that is the intendedly rational attempt to tailor one's network in line with the specific individual needs and opportunities that present themselves (for a review of network agency see Tasselli \& Kilduff, 2021; for the context of network mobilization see Small, 2021). Institutions do not affect behavior directly, yet they do provide a framework for the decisions individual actors take (see also Beckert, 2010). What does all this mean in practice? Rich empirical research illustrates the related mechanisms connecting institutions and network contacts in China.

The value of political ties A central difference between emerging/transition versus developed economies is the quality of institutions: government regulation, rule of law, voice, and accountability. The more regulation, less rule of law, less voice, and less accountability exist, the more leeway there is for government and political representatives to intervene in market outcomes. Nee and Opper (2007) coined the term politicized capitalism for systems characterized by substantive overlap between the economic and political spheres (more neutrally, Boisot and Child (1996) refer to network capitalism). On the one hand, state policies reserve distinctive functions for party and government representatives not common in liberal market economies and designed to establish a closer proximity between management and party representatives. ${ }^{1}$ On the other hand, managers and firms are incentivized to seek and cultivate political ties inside and outside the organization because politicians and government representatives enjoy considerable discretion in their role as gatekeepers in most of

\footnotetext{
1 For instance, China's Company Law (Article 19) makes it mandatory for every company to have a Communist Party unit within its organization, which (according to the Constitution of the CCP, Article 33 ) is charged to "promote the healthy development of the enterprise." For full text, see http://www. xinhuanet.com//english/download/Constitution_of_the_Communist_Party_of_China.pdf .
} 
China's factor markets (Boisot \& Child, 1996). The promise is to gain privileged access to resources and information that continue to be tightly regulated. Political and government ties may also help secure favorable treatment in the form of subsidies and tax breaks and supportive infrastructure investments. Finally, political ties can offer protection against arbitrary political interference, unfair court rulings, and expropriation of profits and assets in the absence of secure, legally enforceable property rights.

Unsurprisingly, study of political connections figures prominently in strategy research on China. Most studies have looked at individual dyads connecting managers, entrepreneurs, or-more broadly_organizations with government and party. Two empirical strategies dominate. Initial studies used a direct approach, asking firm managers and entrepreneurs about their relations with government and party. Xin and Pearce (1996: 1652-3) paved the way by asking firm managers to name 8 to 10 contacts most valuable for their business. They found that on average, private firms and collective firms had more connection with government than state-owned firms did, and this is in line with our general rule that ties are institutionally shaped by defining those who hold access to capital and those who need the respective type of capital. In China's early reforms, private firms had the strongest need for good relations because of the weak organizational legitimacy of capitalist forms of production (Nee \& Opper, 2012). Peng and Luo (2000) followed Xin and Pearce's lead and confirmed the value of political ties for firm performance. ${ }^{2}$

A second, more indirect operationalization strategy in political capital research looks for attributes in managers and entrepreneurs that suggest—but do not directly capture-the existence of political ties. For firm managers or entrepreneurs, the most commonly employed proxies include CCP party membership, membership of China's Political Consultative Conference (CPCC), holding a formal party position (such as party secretary), and a former role in government. Much of this research has linked political attributes with distinct transactions such as applications for and availability of corporate bank loans. The cumulative results provide broad confirmation of the general rule that political ties matter (Ge et al., 2017; Li et al., 2008; Nee \& Opper, 2010, 2012; Zhao \& Lu, 2016), yet less so once markets mature (Li et al., 2008) and the quality of intermediary institutions improves (Zhao \& Lu, 2016). Few have directly analyzed the association between political ties and a firm's strategic orientation. Building on the presented evidence, however, one can assume that political ties are of lesser importance for exploratory innovation activities and are rather associated with exploitative activities, an inference that Wang et al. (2020) confirm in their study of 400 firms in China's semiconductor and pharmaceutical industries.

Business ties What about business ties? Do networks reflect the individual needs of managers and entrepreneurs seeking to establish themselves alongside a powerful and consistently supported state-owned and state-controlled sector? Qualitative

\footnotetext{
${ }^{2}$ In their survey, Peng and Luo (2000) asked managers to what extent they "utilized personal ties, networks, and connections" in their exchange with (1) political leaders, (2) officials in industrial bureaus, and (3) officials in regulatory and supporting government organizations.
} 
case studies suggest that they do. Nee and Opper's (2012) detailed report on private firms in China's Yangzi Delta region documents how firm managers-mindful of weak legitimacy and limited resource access - developed norms of mutual help. Against the shared notion, that "it is impossible to just rely on yourself" in an environment characterized by tight market regulations and weak rule of law, many managers emphasize the crucial support they activate through their business networks. Whether support is needed in the form of informal types of cooperation in innovation projects, mutual lending to replace difficult to obtain bank loans, or information sharing regarding the reputation of would-be suppliers and clients, the value of business contacts is often grounded in their ability and willingness to provide information and informal services that would otherwise be more difficult to obtain.

Just as managers and entrepreneurs are keenly aware of the political ties they need for specific transactions and projects, they are reflective and pragmatic about their business ties and the types of associations required to develop their business. In particular, boundary spanning activities and exploratory tasks are associated with valued business contacts. Nee and Opper's (2012) Chapter 8 on innovation activities of their sample of 700 entrepreneurs is instructive: $82 \%$ of their survey participants said they get ideas for innovation projects from their customers and $50 \%$ listed other companies in the same industry, yet only 3\% mentioned political ties as valuable. Business contacts are not only crucial for idea generation; formal and informal collaborations are key in R\&D.

The nature of the business contacts managers cultivate mirrors the institutional logics under which individual firms operate. The same study documents, how China's entrepreneurs seek out certain connections and avoid others. As one entrepreneur explains, "of course, one may encounter quality problems with products from private companies, but private companies will always try to adjust. Township and village enterprises, in contrast, would not pay attention to our complaints" (Nee \& Opper, 2012: 169). The reason is that contracts are more likely to be followed and honored if both partners face the same or similar institutional conditions and therefore understand the other's constraints. The great majority of managers of private firms intuitively follow the same logic. Out of 700 private firm managers interviewed in 2006, 74\% stated that their key supplier was another private firm (Nee \& Opper, 2012: 152); the corresponding share was over $80 \%$ in a repeat of the survey conducted in 2012 (unpublished survey data), which corroborates how closely business ties map to specific strategies.

\section{Institutions and network structure}

Broadly speaking, social networks are made up of a set of social actors (such as individuals or organizations), a set of dyadic ties, and other social interactions between actors. In business and economic development, social networks matter for two main reasons: First, networks provide the social foundation of trust (Coleman, 1988, 1990; Granovetter, 1985). Second, the specific structure of social networks 
influences access to and the flow of information, ideas, and resources across social clusters (Burt, 1992; Granovetter, 1973).

Network mechanisms are universal The production of personalized trust or in-group trust relies on the existence of close and frequent exchange relations and is therefore highest in networks that are rich in mutually connected contacts. In such networks, bad behavior of individual members does not go unnoticed, the threat of individual and community sanctions is imminent, and-as a consequence-members have good reason to comply with in-group norms of good behavior. The result is high in-group trust (Coleman, 1988, 1990) and stability of interpersonal relations (Feld, 1997). The safe haven that closed networks provide is helpful for in-group coordination, the refinement of existing procedures, and to generate productive value from exploitation tasks. The downside is that closed networks are rich in redundant ingroup information. Referring to the folk wisdom that social networks are all about "who you know" (as in the relational perspective), the problem in closed networks is that "everybody you know also knows everybody else you know." Clearly, such mutually connected acquaintances cannot entail privileged information or resource access. Moreover, closed networks are associated with behavioral pathologies because they tend to nurture distrust (Cook et al., 2009), impede cooperation with outsiders (Burt et al., 2021a; Gargiulo \& Benassi, 2000), and limit strategic and long-term planning (Burt \& Soda, 2017; Opper \& Burt, 2021). In contrast, open networks excel here. Open networks contain ties that bridge across different social clusters and thereby increase opportunities to come across novel information, ideas, and resources. Broadly speaking, broker advantage comes from information breadth, timing, and arbitrage (Burt et al., 2013). That is, brokers benefit from: (1) their ability to reach a broader range of non-redundant information; (2) being able do so in a timely manner; and (3) value creation by moving resources and ideas from familiar to unfamiliar and productive settings.

In reality, almost no network is completely closed or entirely open. Almost all network structures locate somewhere on the continuum between complete closure (everybody knows everybody else) and complete openness (no ties are mutually connected). Yet there is robust evidence that organizations and managers in socalled broker positions are more likely to outperform others in terms of individual career advancement, performance evaluations, business performance, innovation, and creativity (for a recent review, see Burt, 2021).

The described network structure-performance association is general. Managers and firms surrounded by open networks tend to be associated with better performance, whether in the US, Europe, or China (for a review of comparative research and evidence, see Burt \& Batjargal, 2019). Although some studies have suspected an Asian cultural contingency in the network structure-performance association (see, for instance, Xiao \& Tsui, 2007), there is accumulating evidence that the association is indeed general (Batjargal, 2007a, 2007b, 2010b; Batjargal et al., 2013; Burt \& Burzynska, 2017). Further, there is no indication that the association hinges on distinct organizational forms; effects have been found to be comparable for family and non-family firms in China (Burt et al., 2021b). Finally, holding constant especially valuable ties - such as political connections-does not trump the general association 
between network structure and performance. Offering a novel approach that integrates multiple proxies of political connection and disconnection with network structure, Burt and Opper (2020) show that managers surrounded by more open networks run more successful firms, even though political connection and political disconnection add positive and negative adjustment effects, respectively.

Network styles vary with institutions Confirmation of the same network-performance association across countries is not the same as saying "networks look the same globally." Differences in composition and structure are likely. Given the specific properties and relative advantage of distinct network structures-with high insider trust in closed networks versus information heterogeneity in open networks - the balance between closure and openness should vary not only with the purpose of the group's activity (strategies of exploitation versus exploration, see Lazer \& Friedman, 2007), but also across institutional settings. Beckman et al. (2004), for instance, study the 300 largest US firms and show that partner selection correlates with market uncertainties. The authors show that periods of high market uncertainties are associated with the reinforcement of existing alliances, whereas in times of market certainty firms tend to broaden their alliances. Beckman and colleagues do not study institutional qualities but market signals (stock price volatility), yet their results are consistent with the idea of individual and corporate embeddedness shaping partner selection.

Looking at the national and sub-national institutions of emerging and transition economies, the expectation is that interpersonal trust within business networks becomes relatively more valuable if government cannot or does not provide the requisite formal institutions to protect business transactions. In the extreme case of an anarchic state, the only trusted people are likely to be found in the inner, closed circle of core family members. In contrast, if generalized trust is sufficiently high and law enforcement is predictable, in-group trust will lose some of its relative value. Inclusion of less familiar, outside contacts is likely to generate greater productive value. Briefly, institutional profiles define what type of social network generates relatively more advantage and incentivize agents to build and sculpt the type of network they need (see also Owen-Smith \& Powell, 2008: 603).

Qualitative research has detailed the role of supportive network mechanisms both in premodern societies (Greif, 1989) and modern societies (Bernstein, 1992; Ellickson, 1991; Nee \& Opper, 2012), with implicit reference to the way institutional context shapes and nourishes network structure (Powell et al., 2005; Saxenian, 1994). Quantitative evidence of the institution-network structure association, however, remains scarce. One reason is a preference for the single-country framework in empirical studies, with the US receiving most attention (exceptions are: Batjargal, 2007a, 2010b; Batjargal et al., 2013). The other is that longitudinal network studies are equally rare. This rules out standard identification strategies. To be completely sure of the exact association would require parallel international research efforts.

Bits and pieces of quantitative evidence, however, add up to a discernable image that associates average levels of network closure with institutional conditions. Batjargal (2010b) uses network data collected in 2003 to compare the business networks of software entrepreneurs in Beijing (China) and Moscow (Russia) and 
finds that the networks around Chinese entrepreneurs were, on average, significantly smaller and more closed than those around Russian entrepreneurs. Many explanations come to mind, but institutional differences are a strong contender because at the time of the survey entrepreneurs in Russia enjoyed significantly better regulation, more rule of law, and more government accountability than those in China. ${ }^{3}$

Consistent findings come from two of my own data collection surveys in China. Both surveys shared the same network instrument, and both approached a sizeable random sample of managers of private firms in China's Yangzi delta region. The first survey was conducted in 2012 (reaching 700 managers in seven cities); the second was conducted in 2018 (reaching 384 in three of the seven cities). Using this data and measuring network closure using Burt's (1992) network constraint score (whereby a value of 1 indicates a small, closed network and a value of 0 indicates a large, open network around the manager) corroborates a link between regional institutional quality and network structure. Whereas the first survey generated an average network constraint score between 0.54 (in Shanghai) and 0.61 (in Ningbo), ${ }^{4}$ six years later the corresponding values were 0.40 (in Shanghai) and 0.43 (in Ningbo). Two points are important: (1) Managers operating businesses in Shanghai's more mature and cosmopolitan environment maintain on average more open business networks than those in Ningbo; and (2) with time and increasing market liberalization, business networks around China's managers become on average more open and more similar across regions.

The association between institutions and network structure is also reflected in the changing nature and advantage of network structure as novel firms gain organizational and institutional legitimacy. Using the same survey data from 2012, Burt and Opper (2017) show that newly founded private firms enjoy performance advantages if the network around the CEO was relatively closed at the founding stage. It seems that closed networks function as a protective "cocoon" for firms that are new and therefore often seen as semi-legitimate. As these firms become institutionalized and survive the first years in business, however, the very advantage of network closure around the manager turns into a disadvantage. Over time, firms perform better and grow faster if their managers leave their protective cocoon and reach out to different social clusters.

Burzynska and Opper (2020) test more directly the network structure performance association across different institutional settings. In their study of lending networks in China they exploit sub-national institutional variation across China's provinces and show that if formal institutions are weak and weakly enforced, closure in banking relations around the corporate borrower helps to secure larger amounts of capital. This result is consistent with the need for more effective information exchange and monitoring, best achieved by close-knit groups, if institutions

\footnotetext{
${ }^{3}$ In 2002, the year of Batjargal's survey, Russia's global rankings in terms of regulatory quality, rule of law, and voice \& accountability were in the 45 th, 43rd, and $23 \mathrm{rd}$ percentiles, respectively. In contrast, China is ranked lower with corresponding values in the 34 th, 37th, and 7th percentiles, respectively (World Bank, 2020; https://databank.worldbank.org/source/ worldwide-governance-indicators).

${ }^{4}$ Both values signal greater openness than Batjargal's (2010b) survey conducted 9 years earlier in Beijing.
} 
are weak. The closure advantage disappears when the institutional environment around the corporate borrower matures. Institutional oversight and reliable third party enforcement replaces the necessity for private ordering within relatively small groups of well-connected actors.

Clearly, more evidence is needed to reliably disentangle the association between institutions and network structure from correlates such as strategy, sector, type of transaction, and organizational form. Available evidence, however, indicates that performance variations in local network-strategy fit are rooted in the institutional context.

\section{Social networks shape institutions}

Social networks shape institutions and institutional change in two ways: First, networks predict innovativeness, without which any deviation from common practice would be impossible; second, network structure and the staffing of networks influence the diffusion of institutional innovation.

Innovation is only an individual endeavor in exceptional cases. Instead, innovation builds on accumulated knowledge and is grounded in the exchange of diverse specialist knowledge and experience. Schumpeter's (1934) understanding of innovation as a process of reorganization and recombination of existing resources and knowledge has shaped much of this understanding. The social embeddedness of innovation is here implicit. The more freely ideas and resources can move between different contacts and groups, the more likely are "productive accidents" where novel products and processes emerge from recombination (Burt, 2005: 95; Burt, 2010: 5).

There is ample evidence that innovation, creativity, and even organizational changes are more likely in open than in closed networks (Battilana \& Casciaro, 2012; Burt, 2004; Fleming et al., 2007; Perry-Smith \& Mannucci, 2017). Two mutually reinforcing qualities of open networks are key to open networks offering a structural advantage. There is easy access to diverse ideas, knowledge, and opinions. Moreover, open networks nurture distinct capabilities and behavioral styles. With their inbuilt exchange of different opinions, jargons, and world views, open networks tend to foster debate, productive controversy, and creative thinking. In this way, open networks nurture a cooperative behavioral style likely to facilitate innovation activities (Burt et al., 2021a; Quintane \& Carnabuci, 2016).

Much of social network research has looked at firm level innovation. However, institutional and organizational innovation are equally shaped by open social structures connecting actors across social clusters. The far-reaching transformation of Haier, the Chinese appliance maker, from a monolithic, hierarchical corporation into an open network of more than 4000 independent microenterprises is one of the largest top-down experiments, designed to unleash institutional and organizational innovation by capitalizing on the productive power of open social structures (Hamel \& Zanini, 2018). Haier's micro-entrepreneurs have the right to freely decide with whom (whether inside or outside of Haier) they collaborate. The management also 
launched an open talent platform to invite the best global talent for specific projects. A constant process of new alliance formation and tie decay has become part of Haier's organizational and business routine, placing Haier today reliably among the most innovative global corporations.

Grassroots innovation of local institutions follows similar principles. Typically, peripheral actors move new ideas from one group to another. After different ways of doing things have proven successful within a small group of pioneers, imitators follow-initially mostly close and trusted contacts such as friends and family, then more distant acquaintances. With time, commonly accepted business norms emerge which draw in even more followers. Local islands of institutional innovation evolve and word spreads to neighboring communities and regions about new and more successful ways of doing business. This is how Wenzhou's entrepreneurs-pioneers in China's movement toward a private firm economy (Nee \& Opper, 2012; Parris, 1993) - acquired country-wide recognition and followers, long before the state put in place the Property Rights Law (in 2007) and constitutionally guaranteed rights of equal treatment for different forms of ownership.

Not all institutional innovations diffuse as rapidly as China's bottom-up entrepreneurial movement. This poses the question how social networks contribute not just to innovativeness but also to the spread of novelty-whether in the form of institutions or new business models. We know little about the precise predictors of institutional emergence, but factors that matter include individual gain or the incentive to deviate from one practice to explore another, opportunity costs and perceived risks, and the state's interest in defending the established institutional order (Nee \& Opper, 2012). Likewise, it is obvious that social network structure influences whether novel institutions can take hold. Some examples illustrate the point. Looking at the spread of private firms in China, Peng (2004) has explored population data from 366 Chinese villages to uncover a statistically significant association between kinship networks and the diffusion and success of private firms as a new way of doing business. More specifically, Peng shows that the local number of firms and firm size are positively correlated with the relative importance of the strongest kin in each village. Although Peng has no data on network structure, it is implicit that in-group trust and kin solidarity were important in the initial stage of institutional innovation and the establishment of new local rules. Similarly, Dai et al. (2019) relate population density with diffusion of private firms. A shared point in both studies is that early stage institutional innovation and local replication require some level of density and closure, providing a safe and supportive space for those engaging in novel and therefore uncertain activities.

For macro-diffusion of novel institutions, however, the status of early adopters and mutual connectedness also matter. Davis and Greve (1997) have explored the role of America's corporate elite in the diffusion of new institutional solutions, highlighting how interpersonal networks between corporate boards accelerate the diffusion of institutional innovations. Similarly, in international diffusion processes, professional associations have turned out to be instrumental. Djelic's (2004) analysis of the diffusion of the American business model in France after 1945 highlights the balance between outreach and network closure. Weak ties have proven crucial in 
disseminating information across borders and strong ties to the national establishment have helped to legitimize the American model in France.

The China Entrepreneur Club (CEC) offers an interesting analogy. The club was formed in 2006 as an alternative to the official private entrepreneur organization, the All China Federation for Industry and Commerce, and the China Entrepreneur Forum (CEF). Currently, the CEC lists 60 members on its webpage, ${ }^{5}$ a number that is unlikely to increase beyond 100 due to the club's interest in keeping the network small enough to guarantee personalized exchange and high in-group trust. The club members emphasize the vast in-group heterogeneity. Only leaders of their respective industry niche such as Alibaba's Jack Ma—currently the CEC's chairman-Geely's Li Shufu, and Xiaomi's Lei Jun are admitted. Duplication of industrial specialization is rare, which guarantees easy access to the broadest set of business and political audiences in China and abroad, and many of its most prominent members also hold positions in China's National People's Congress. With direct access to the country's lawmaking body, the group's influence on China's institutional and strategic development is exemplary, even though it continues to be limited by clear boundaries drawn by political state priorities (Nee \& Opper, 2012: ch. 2; see also He \& Disis, 2021).

\section{Future research: Institution-based strategy and network capabilities}

When Peng (2002) first advocated institution-based strategy research in this journal, he asked: Why are there so many different firm strategies globally? Already then, he highlighted one crucial difference: Strategies in emerging and transition economies rely far less on arm's-length market transactions than on network-based exchange. That networks matter has since become a wildly popular claim, even though the majority of institutional work does not go beyond ceremonial reference to the importance of relational ties and informal contracting. Cumulative evidence presented here suggests that institution-based research has much to gain from an even closer and systematic integration of social network mechanisms. This is largely due to the demonstrated co-constitutional nature of institutions and networks, whichby derivation-implies that the search for the right institutions-strategy fit also requires a distinct network style and structure. In the search for appropriate, that is performance-enhancing network-strategy fit, I identify four fruitful areas for future research.

\section{Social network and adaptive strategy}

Successful adaptation to local institutions hinges on local knowledge acquisition. A common strategy to close knowledge gaps-which can exist not only between regions or countries but also across industries-are strategic alliances, especially

\footnotetext{
${ }^{5}$ www.daonong.com
} 
equity joint ventures, which promise immediate access to local, specialized knowledge and supply and distribution channels (Makino \& Delios, 1996). The relational dimension in strategic alliances is obvious. Empirical research in strategy, however, has largely omitted the relevance of network-strategy fit. There are some exceptions: Shi et al. (2012), for instance, explore how social embeddedness and the institutional environment have jointly affected a firm's likelihood of being selected as a joint venture (JV) partner in China. Their results show that in a population of publicly-listed electronics and technology firms, if institutions are weak, Chinese JV partners are more likely to occupy broker positions. In contrast, if market institutions are strong, local JV partners are more likely to hold central network positions (a position typically held by high status firms, see Podolny, 1993). In a related paper, using the same data, Shi et al. (2014) further show that broker networks of local JV partners become more attractive if foreign investors have already gained local market experience and select local partners for their connectedness, rather than for their capability attributes.

One is reluctant to generalize from a single sample, especially because alliance formation in China is likely subject to political involvement. Furthermore, both papers focus on organizational ties and do not feature data on the personal networks around corporate leaders, which leaves the nature of operational agency and governance unexplored. Yet one can think of a number of productive ways to proceed from here. Guiding questions include: Where exactly are alliance partners positioned in their respective personal network? Given the institutional embedding of the business, do partners have the right mix of business and political affiliations? Are alliance partners in fact able to reach relevant local contacts? Finally, given the implicit ambition to gain access to local knowledge through a local partner's network contacts, a key question is whether partner organizations are even willing to let their new partner join their network ("tertius iungens brokerage"- the third who joins) or whether they are keeping their local network contacts apart ("tertius separans brokerage" - the third who separates; see Burt, 2021; Obstfeld, 2005)? In the latter case, a knowledge-seeking firm or organization would in fact be locked into a highly dependent position with access only to partner-controlled information. To illustrate, JVs promise access to local knowledge and market experience. In this sense, they have been long heralded as a convenient strategy to adapt to unfamiliar host environments. However, knowledge access is a matter of relational agency. Similarly, government ownership of JV partners certainly increases opportunities to secure favorable treatment in highly state-regulated markets, although political ties require careful management. In their comparison of Volkswagen's and General Motor's respective experiences with the same local, highly politically embedded JV partner (SAIC), Sun et al. (2010) highlight the critical role relationship management played in the development of supply chains, pricing, and local sales. Volkswagen's initial dependence on its local JV partner SAIC for supplier selection in contrast is reminiscent of a "tertius separans-conflict" (Burt, 2021). Hence, the difference between the two entry strategies is not the choice of strategy, but the network-strategy fit.

Many shy away from the intrinsic risks that strategic alliances pose. In China, equity joint ventures (EJVs) recently account for no more than $25 \%$ of utilized foreign investments (China Statistical Yearbook, 2019: Table 11-15). This forces the 
majority of foreign investors to develop their own local network, just as domestic entrepreneurs do. In such cases, the question for the appropriate network-strategy fit is the same as for any domestic producer seeking to adapt to local institutional logics by building the right ties with business and government partners, with the right level of openness to pursue either exploitative or exploratory activities. These networks are likely to differ somewhat by industry, scale of production, and production technology, to name just a few factors, because these attributes influence what types of gatekeepers and resources corporations depend on in pursuit of their specific strategies. Compare, for instance, the very different supply chains that a technology firm such as Apple and a textile producer such as H\&M depend on. Both call for substantively different associations within and across economic and political spheres.

\section{Social network and change strategies}

Entering emerging economies or even seeking to establish a new market niche on the premise of gradually changing the host's institutional environment requires distinct managerial networks. For social networks to affect institutional change, networks need to strike a balance between closure and bridge ties. A level of closure among like-minded actors deviating from established institutional practice is needed to provide a trusted and secure social space for institutional experiments, especially if the new rules of the game are socially ostracized, broadly understood as an illegal or semi-legal deviation from established practice and social norms. Bridge ties, in turn, will be required to diffuse change beyond the boundaries of localized experiments and to eventually legitimize novel practice. A widely reported case is the bottom-up dissolution of China's people's communes, a grassroots effort initiated in the poor and highly populated provinces of Anhui and Sichuan, which in time gained central government recognition and eventually morphed into national campaigns to decollectivize agricultural production (Opper, 2021).

Markóczy et al. (2013) are among the few who have analytically studied the link between a firm's network position and institutional innovation in China. Their focus is on the association between network position and corporate attempts to break away from the social norm of low CEO compensation. In line with the argument made here, the authors find that centrally located firms enjoyed the liberty to deviate from common practice. Peripheral firms in brokerage positions, in contrast, were more constrained in their corporate decisions. Lack of network support around the firm led to the ceremonial introduction of symbolic steering committees to introduce and internally justify novel payment schemes. Similar to Markóczy et al.'s (2013) application, there are many change strategies that deserve closer attention. These include corporate strategies to import novel standards of supply-chain management, introduction of novel financial services and related rules, and labor, environmental, and safety standards, to name just a few. None of these changes are likely to succeed in isolation and depend on the social embeddedness of local innovation and the broader acceptance and ultimately formal standardization of good practice. 


\section{Institutional dynamics and network-strategy fit}

The personal networks around managers are, of course, not static but dynamic. Contacts are added and other ties are severed, often without affecting the overall network structure. There is substantive evidence showing that networks tend to be self-reinforcing in the sense that individuals with open (or closed) networks tend to rebuild similar networks over time (Burt \& Merluzzi, 2016; Sasovova et al., 2010; Zaheer \& Soda, 2009). For the specific research question posed here, we are less interested in network dynamics at large than in the way institutional change affects a given network-strategy fit.

Through a network lens, changes in institutions imply that any or all of the following happen: (1) Opportunities for tie formation change; (2) control rights over certain types of capital shift; and (3) dependents on certain types of capital change. What once seemed like a valuable alliance may become worthless. Well documented examples include the sudden removal of government officials due to anti-corruption campaigns (Burt \& Opper, 2020), turnover of political regimes (Darendeli \& Hill, 2016), or routine turnover of responsible staff in partner organizations (van Honecker, 2004). Equally, what once looked like a particularly poor alliance to form, may turn into a sought-after tie. What seemed to be the right trust-producing network structure may no longer be a valuable network quality; and what seemed to be the right network structure to reach across social clusters may involve too much risk if formal institutions deteriorate. Finally, the entry of new institutions into country profiles may completely shape and reshape partner selection. See, for instance, Menzel et al. (2017) on changes in tie formation in response to the rise of a local venture capital industry. These observations support theoretical arguments highlighting the need for continuous adjustments in network relations in light of environmental changes, and reject the idea of culturally distinct and therefore stable network preferences (Bian \& Zhang, 2014; Chang, 2011; Peng \& Zhou, 2005). As a derivation, finding and maintaining a productive network-strategy fit requires continuous network agency and managerial adaptability. Central questions to ask here are: What factors facilitate flexible adjustment processes of managerial networks? Which factors are likely to lead to costly lock-in effects undermining corporate performance?

\section{Institutional distance and network-strategy fit}

For foreign investors, the challenge of cultivating managerial networks tailored to support strategic goals in institutionally distant host environments is complicated by tensions between home and host institutions. One issue deserving closer attention is the influence of institutional and cultural distance in networking behavior. How will institutional and cultural tensions influence the identification of a productive network-strategy fit? Foreign investors, whose business networks and capabilities were groomed and developed in their specific home environment, are likely to have acquired a style not equally suited to institutionally different host environments. (On the forcing function of network style, see Burt, 2010; Burt et al., 2021a; Quintane \& Carnabuci, 2016.) Second, there is the question of to what extent variable audience 
expectations influence subsidiary strategies. A common concern for Western multinational enterprises (MNEs), for instance, is the management of political ties. Home audiences in the West tend to disapprove of overly close political ties, especially with leaders in non-democratic systems. Case evidence documents how lack of experience and differences in headquarters and subsidiary expectations can lead either to political over-embeddedness or lack of relevant ties (Sun et al., 2010). A closely related question is how the relationship management of international investors can be shielded from exogenous shocks rooted in changes in bilateral relations, tendencies of nationalism, and patriotism in home and subsidiary locations.

\section{Conclusion}

The purpose of this paper is to argue the merits of a tighter integration of quantitative network analysis into institution-based strategy research. The central theme has been that distinct institutional settings not only call for "fitting strategies" but also require an appropriate network style. The examples discussed corroborate the value of such an approach and substantiate promising areas for future research. Theory refinement will come from cumulative findings and repeat validation across variable institutional settings. In the past, we have learned much about institution-based strategy choice. For a better understanding of strategy implementation, greater attention to network strategies and institution-specific network-strategy fit offers a promising path. Insights from such a research program would not only enrich global strategy research, but also contribute to an emerging dialogue between institutional and social network theories.

Open Access This article is licensed under a Creative Commons Attribution 4.0 International License, which permits use, sharing, adaptation, distribution and reproduction in any medium or format, as long as you give appropriate credit to the original author(s) and the source, provide a link to the Creative Commons licence, and indicate if changes were made. The images or other third party material in this article are included in the article's Creative Commons licence, unless indicated otherwise in a credit line to the material. If material is not included in the article's Creative Commons licence and your intended use is not permitted by statutory regulation or exceeds the permitted use, you will need to obtain permission directly from the copyright holder. To view a copy of this licence, visit http://creativecommons.org/licen ses/by/4.0/.

\section{References}

Ahlstrom, D., \& Bruton, G. D. 2006. Venture capital in emerging economies: Networks and institutional change. Entrepreneurship Theory \& Practice, 30(2): 299-320.

Baker, W. E. 1984. The social structure of a national securities market. American Journal of Sociology, 89(4): 775-811.

Batjargal, B. 2007a. Comparative social capital: Networks of entrepreneurs and venture capitalists in China and Russia. Management and Organization Review, 3: 397-419.

Batjargal, B. 2007b. Internet entrepreneurship: Social capital, human capital, and performance of internet ventures in China. Research Policy, 36: 605-618. 
Batjargal, B. 2010a. Network dynamics and new ventures in China: A longitudinal study. Entrepreneurship \& Regional Development, 22: 139-153.

Batjargal, B. 2010b. The effects of network's structural holes: Polycentric institutions, product portfolio, and new venture growth in China and Russia. Strategic Entrepreneurship Journal, 4: 146-163.

Batjargal, B., Hitt, M. A., Tsui, A. S., Arregel, J.-L., Webb, J. W., \& Miller, T. L. 2013. Institutional polycentrism, entrepreneur's social networks, and new venture growth. Academy of Management Journal, 56: 1024-1049.

Battilana, J., \& Casciaro, T. 2012. Change agents, networks, and institutions: A contingency theory of organizational change. Academy of Management Journal, 55: 381-398.

Beckert, J. 2010. How do fields change? The interrelations of institutions, networks, and cognition in the dynamics of markets. Organization Studies, 31: 605-627.

Beckman, C. M., Haunschild, P. R., \& Phillips, D. J. 2004. Friends of strangers? Firm-specific uncertainty, market uncertainty, and network partner selection. Organization Science, 15(3): 259-275.

Berman, D. 2011. When global value chains are not global: Case studies from the Russian fast-food industry. Competition and Change, 15(4): 274-295.

Bernstein, L. 1992. Opting out of the legal system: Extralegal contractual relations in the diamond industry. Journal of Legal Studies, 21: 115-152.

Bian, Y., \& Zhang, L. 2014. Corporate social capital in Chinese guanxi culture. Research in the Sociology of Organizations, 40: 417-439.

Boddewyn, J. J., \& Peng, M. W. 2021. Reciprocity and informal institutions in international market entry. Journal of World Business, 56: 101145.

Boisot, M., \& Child, J. 1996. From fiefs to clans and network capitalism: Explaining China's emerging economic order. Administrative Science Quarterly, 41: 600-628.

Brass, D. J., Galaskiewitz, J., Greve, H. R., \& Tsai, W. 2004. Taking stock of networks and organizations: A multilevel perspective. Academy of Management Journal, 47(6): 795-817.

Bruton, G. D., Ahlstrom, D., \& Chen, J. 2021. China has emerged as an aspirant economy. Asia Pacific Journal of Management, 38(1): 1-15.

Burt, R. S. 1992. Structural holes. Harvard University Press.

Burt, R. S. 2004. Structural holes and good ideas. American Journal of Sociology, 110: 349-399.

Burt, R. S. 2005. Brokerage and closure. Oxford University Press.

Burt, R. S. 2010. Neighbor networks. Oxford University Press.

Burt, R. S. 2021. Structural holes. Capstone, cautions, and enthusiasms. In M. L. Small, B. L. Perry, B. Pescosolido, \& E. B. Smith (Eds.). Personal networks. Cambridge University Press.

Burt, R. S., \& Batjargal, B. 2019. Comparative network research in China. Management and Organization Review, 15(1): 3-29.

Burt, R. S., \& Burzynska, K. 2017. Chinese entrepreneurs, social networks, and guanxi. Management and Organization Review, 13(2): 221-260.

Burt, R. S., Kilduff, M., \& Tasselli, S. 2013. Social network analysis: Foundations and frontiers on network advantage. Annual Review of Psychology, 64: 537-547.

Burt, R. S., \& Merluzzi, J. 2016. Network oscillation. Academy of Management Discoveries, 2(4): 368-391.

Burt, R. S., \& Opper, S. 2017. Early network events in the later success of Chinese entrepreneurs. Management and Organization Review, 12(3): 497-537.

Burt, R. S., \& Opper, S. 2020. Political connection and disconnection: Still a success factor for Chinese entrepreneurs. Entrepreneurship Theory and Practice, 44(6): 1199-1228.

Burt, R. S., Opper, S., \& Holm, H. J. 2021a. Cooperation beyond the network. Organization Science, in press. https://doi.org/10.1287/orsc.2021.1460.

Burt, R. S., Opper, S., \& Zou, N. 2021b. Social network and family business: Uncovering hybrid family firms. Social Networks, 65(April): 141-156.

Burt, R. S., \& Soda, G. 2017. Social origins of great strategies. Strategy Science, 2: 226-233.

Burt, R. S., \& Soda, G. 2021. Network capabilities: Brokerage as a bridge between network theory and the resource-based view of the firm. Journal of Management, forthcoming.

Burzynska, K., \& Opper, S. 2020. Interbank relations, environmental uncertainty, and corporate credit access in China. Management and Organization Review, 16(3): 595-628.

Carney, M., Gedajlovic, E., \& Yang, X. 2009. Varieties of Asian capitalism: Toward an institutional theory of Asian enterprise. Asia Pacific Journal of Management, 26: 361-380.

Chang, K. C. 2011. A path to understanding guanxi in China's transitional economy: Variations on network behavior. Sociological Theory, 29(4): 315-339. 
Chen, V. Z., \& Sun, S. L. 2019. Barbarians at the gate of the middle kingdom: The international mobility of financial contracting and governance. Entrepreneurship Theory and Practice, 43(4): 802-837.

Coleman, J. S. 1988. Social capital and the creation of human capital. American Journal of Sociology, 94: 95-120.

Coleman, J. S. 1990. Foundation of social theory. Harvard University Press.

Cook, K. S., Levi, M., \& Hardin, R. 2009. Whom can we trust? Russell Sage Foundation.

Dai, R., Mookherjee, D., Munshi, K., \& Zhang, X. 2019. The community origins of private enterprise in China. The Institute of Economic Development Working Paper Series N. DP-320. Boston University.

Darendeli, I. S., \& Hill, T. L. 2016. Uncovering the complex relationships between political risk and MNE firm legitimacy: Insights from Lybia. Journal of International Business Studies, 47: 68-92.

Davis, G. F., \& Greve, H. R. 1997. Corporate elite networks and governance changes in the 1980s. American Journal of Sociology, 103(1): 1-37.

Demsetz, H. 1992. Economic, legal and political dimensions of competititon. North Holland.

Dixit, A. K. 2004. Lawlessness and economics: Alternative modes of governance. Princeton University Press.

Djelic, M. L. 2004. Social networks and country-to-country transfer: Dense and weak ties in the diffusion of knowledge. Socio-Economic Review, 2: 341-370.

El Ghoul, S., Guedhami, O., \& Kim, Y. 2017. Country-level institutions, firm value, and the role of corporate social responsibility initiatives. Journal of International Business Studies, 48: 360-385.

Ellickson, R. 1991. Order without law. Harvard University Press.

Feld, S. L. 1981. The focused organization of social ties. American Journal of Sociology, 86(5): 1015-1035.

Feld, S. L. 1997. Structural embeddedness and stability of interpersonal relations. Social Networks, 19: 91-95.

Festinger, L., Schachter, S., \& Back, K. 1950. Social pressures in informal groups. Harper.

Fleming, L., Mingo, S., \& Chen, D. 2007. Collaborative brokerage, generative creativity, and creative success. Administrative Science Quarterly, 52: 443-475.

Gargiulo, M., \& Benassi, M. 2000. Trapped in your own net? Network cohesion, structural holes, and the adaptation of social capital. Organization Science, 11(2): 183-196.

Ge, J., Stanley, L. J., Eddleston, K., \& Kellermanns, F. W. 2017. Institutional deterioration and entrepreneurial investment: The role of political connections. Journal of Business Venturing, 32: 405-419.

Granovetter, M. S. 1973. The strength of weak ties. American Journal of Sociology, 78(6): 1360-1380.

Granovetter, M. S. 1985. Economic action and social structure: The problem of embeddedness. American Journal of Sociology, 91(November): 481-510.

Greif, A. 1989. Reputation and coalitions in medieval trade: Evidence on the Maghribi traders. The Journal of Economic History, 49(4): 857-882.

Hamel, G., \& Zanini, M. 2018. The end of bureaucracy: How a Chinese appliance maker is reinventing management for the digital age. Harvard Business Review, November-December: 51-59.

He, L., \& Disis, J. 2021. Can China still lead the world in tech without a new Jack Ma? CNN Business, June 8, https://edition.cnn.com/2021/06/07/tech/china-tech-crackdown-entrepreneurs-intl-hnk/ index.html.

Hitt, M. A., Li, D., \& Xu, K. 2016. International strategy: From local to global and beyond. Journal of World Business, 51: 58-73.

Ioannou, I., \& Serafeim, G. 2012. What drives corporate social performance? The role of national-level institutions. Journal of International Business Studies, 43: 834-864.

Khanna, T., Palepu, K. G., \& Sinha, J. 2005. Strategies that fit emerging markets: 63-76. Harvard Business Review.

Kleinbaum, A. M. 2018. Reorganization and tie decay choices. Management Science, 64(5): 2219-2237.

Kleinbaum, A. M., \& Stuart, T. E. 2014. Inside the black box of the corporate staff: Social networks and the implementation of corporate strategy. Strategic Management Journal, 35: 24-47.

La Porta, R., Lopez-de-Silanes, F., \& Shleifer, A. 1999. Corporate ownership around the world. The Journal of Finance, 54(2): 471-517.

La Porta, R., Lopez-de-Silanes, F., Shleifer, A., \& Vishny, R. W. 1998. Law and finance. Journal of Political Economy, 106(6): 1113-1155.

Lardy, N. 2019. The state strikes back. The Petersen Institute.

Lazer, D., \& Friedman, A. 2007. The network structure of exploration and exploitation. Administrative Science Quarterly, 52: 667-694. 
Leung, K., Bhagat, R. S., Buchan, N. R., Erez, M., \& Gibson, C. B. 2005. Culture and international business: Recent advances and their implications for future research. Journal of International Business Studies, 36: 357-378.

Li, H., Meng, L., Wang, Q., \& Zhou, L. A. 2008. Political connections, financing and firm performance: Evidence from Chinese private firms. Journal of Development Economics, 87: 283-299.

Lin, N. 2001. Social capital: A theory of social structure and action. Cambridge University Press.

Lubman, S. 2006. Looking for law in China. Columbia Journal of Asian Law, 20(1): 1-92.

Ma, X., Yao, X., \& Xi, Y. 2009. How do interorganizational and interpersonal networks affect a firm's strategic adaptive capability in a transition economy? Journal of Business Research, 62: 1087-1095.

Macaulay, S. 1963. Non-contractual relations in business: A preliminary study. American Sociological Review, 28: 55-67.

Makino, S., \& Delios, A. 1996. Local knowledge transfer and performance: Implications for alliance formation in Asia. Journal of International Business Strategies, 27(5): 905-927.

Markóczy, L., Sun, S., Peng, M. W., Shi, W., \& Ren, B. 2013. Social network contingency, symbolic management, and boundary stretching. Strategic Management Journal, 34: 1367-1387.

McPherson, M., Smith-Lovin, L., \& Cook, J. M. 2001. Birds of a feather: Homopily in social networks. Annual Review of Sociology, 27: 415-444.

Menzel, M.-P., Feldman, M. P., \& Broekel, T. 2017. Institutional change and network evolution: Explorative and exploitative tie formations of co-inventors during the dot-com bubble in the research triangle region. Regional Studies, 51(8): 1179-1191.

Meyer, K. E., Estrin, S., Bhaumik, S. K., \& Peng, M. W. 2009. Institutions, resources, and entry strategies in emerging economies. Strategic Management Journal, 30(1): 61-80.

Nandkumar, A., \& Srikanth, K. 2016. Right person in the right place: How the host country IPR influences the distribution of inventors in offshore R\&D projects of multinational enterprises. Strategic Management Journal, 37(8): 1715-1733.

National Bureau of Statistics in China 2019. China statistical yearbook 2019. China Statistics Press.

Nee, V., \& Opper, S. 2007. On politicized capitalism. In V. Nee, \& R. Swedberg (Eds.). On capitalism: 93-127. Stanford University Press.

Nee, V., \& Opper, S. 2010. Political connections in China's market economy. Social Forces, 88(5): 2105-2133.

Nee, V., \& Opper, S. 2012. Capitalism from below. Markets and institutional change in China. Harvard University Press.

North, D. C. 1990. Institutions, institutional change, and economic performance. Cambridge University Press.

Obstfeld, M. 2005. Social networks, the tertius iungens and orientation involvement in innovation. Administrative Science Quarterly, 50(1): 100-130.

Opper, S. 2021. Economic change from an institutional perspective. In A. Maurer (Ed.). Handbook of economic sociology for the 21st century: 177-190. Springer Nature.

Opper, S., \& Burt, R. S. 2021. Social network and temporal myopia. Academy of Management Journal, 64(3): 741-771.

Opper, S., Nee, V., \& Holm, H. J. 2017. Risk aversion and Guanxi activities: A behavioral analysis of CEOs in China. Academy of Management Journal, 60(4): 1504-1530.

Opper, S., Nee, V., \& Brehm, S. 2015. Homophily in the career mobility of China's political elite. Social Science Research, 54: 32-52.

Owen-Smith, J., \& Powell, W. W. 2008. Networks and institutions. In R. Greenwood, C. Oliver, R. Suddaby, \& K. Sahlin-Andersson (Eds.). The sage handbook of organizational institutionalism: 596624. Sage Publications.

Parris, K. 1993. Local initiative and national reform: The Wenzhou model of development. China Quarterly, 134: 242-263.

Peng, M. W. 2002. Towards an institution-based view of business strategy. Asia Pacific Journal of Management, 19(2/3): 251-267.

Peng, M. W. 2003. Institutional transitions and strategic choices. Academy of Management Review, 28(2): $275-286$.

Peng, M. W. 2014. Global strategic management, 3rd ed. Cengage Learning.

Peng, M. W., \& Heath, P. 1996. The growth of the firm in planned economies in transition: Institutions, organizations, and strategic choices. Academy of Management Review, 21(2): 492-528. 
Peng, M. W., \& Luo, Y. 2000. Managerial ties and firm performance in a transition economy: The nature of a micro-macro link. Academy of Management Journal, 43(3): 486-501.

Peng, M. W., Sun, S. L., Pinkham, B., \& Chen, H. 2009. The institution-based view as a third leg for a strategy tripod. Academy of Management Perspectives, 23(3): 63-81.

Peng, M. W., \& Zhou, J. Q. 2005. How network strategies and institutional transitions evolve in Asia. Asia Pacific Journal of Management, 22: 321-336.

Peng, Y. 2004. Kinship networks and entrepreneurs in China's transitional economy. American Journal of Sociology, 109(5): 1045-1074.

Perry-Smith, J. E., \& Mannucci, P. V. 2017. From creativity to innovation: The social network drivers of the four phases of the idea journey. Academy of Management Review, 42: 53-79.

Podolny, J. 1993. A status-based model of market competition. American Journal of Sociology, 8(4): 486-501.

Powell, W. W., White, D. R., Koput, K. W., \& Owen-Smith, L. 2005. Network dynamics and field evolution: The growth of interorganizational collaboration in the life sciences. American Journal of Sociology, 110: 1132-1205.

Quintane, E., \& Carnabuci, G. 2016. How do brokers broker? Tertius gaudens, tertius iungens, and the temporality of structural holes. Organization Science, 27(6): 1343-1360.

Santangelo, G. D., Meyer, K. E., \& Jindra, B. 2016. MNE subsidiaries' outsourcing and insourcing of R\&D: The role of local institutions. Global Strategy Journal, 6(4): 247-268.

Sarma, S., \& Sun, S. L. 2017. The genesis of fabless business model: Institutional entrepreneurs in an adaptive ecosystem. Asia Pacific Journal of Management, 34(3): 587-617.

Sasovova, Z., Mehra, A., Borgati, S. P., \& Schippers, M. C. 2010. Network churn: The effects of selfmonitoring personality on brokerage dynamics. Administrative Science Quarterly, 55: 639-670.

Saxenian, A. 1994. Regional advantage: Culture and competition in Silicon Valley and route 128. Harvard University Press.

Schumpeter, J. 1934. The theory of economic development. Harvard University Press.

Shi, W., Sun, S. L., Pinkham, B. C., \& Peng, M. W. 2014. Domestic alliance network to attract foreign partners: Evidence from international joint ventures in China. Journal of International Business Studies, 45: 338-362.

Shi, W., Sun, S. L., \& Peng, M. W. 2012. Sub-national institutional contingencies, network positions, and IJV partner selection. Journal of Management Studies, 49(7): 1221-1245.

Small, M. L. 2009. Unanticipated gains: Origins of network inequality in everyday life. Oxford University Press.

Small, M. L. 2021. How actors mobilize their networks in practice. In M. L. Small, B. L. Perry, B. Pescosolido, \& E. B. Smith (Eds.). Personal networks. Cambridge University Press.

Small, M. L., \& Gose, L. 2020. How do low-income people form survival networks? The role of routine organizations as brokers. Annals of the American Academy of Political and Social Sciences, 689(May): 89-109.

Sun, P., Mellahi, K., \& Thun, E. 2010. The dynamic value of MNE political embeddedness: The case of the Chinese automobile industry. Journal of International Business Studies, 41: 1161-1182.

Tasselli, S., \& Kilduff, M. 2021. Network agency. Academy of Management Annals, 15(1): 68-110.

Tihany, L., Griffith, D. A., \& Russell, C. J. 2005. The effect of cultural distance on entry mode choice, international diversification, and MNE performance: A meta-analysis. Journal of International Business Studies, 36: 270-283.

UNCTAD 2021. World investment report 2021. Blue Ridge Summit:United Nations Publications.

Van Honecker, W. R. 2004. When good guanxi turns bad. Harvard Business Review, 82: 18-19.

Wang, J. J., Shi, W., Lin, Y., \& Yang, X. 2020. Relational ties, innovation, and performance: A tale of two pathways. Industrial Marketing Management, 89: 28-39.

White, H. C. 1981. Where do markets come from? American Journal of Sociology, 87(3): 517-547.

White, H. C. 2002. Markets from networks. Princeton University Press.

Williamson, O. E. 1985. The economic institutions of capitalism. Free Press.

World Bank 2017. Governance and the law. World Bank Publishing.

World Bank. 2020. Worldwide governance indicators. https://info.worldbank.org/governance/wgi/.

Xiao, Z., \& Tsui, A. S. 2007. When brokers may not work: The cultural contingency of social capital in Chinese high-tech firms. Administrative Science Quarterly, 52: 1-31.

Xin, K. R., \& Pearce, J. L. 1996. Guanxi: Connections as substitutes for formal institutional support. Academy of Management Journal, 39(6): 1641-1658. 
Yiu, D., \& Makino, S. 2002. The choice between joint venture and wholly owned subsidiary: An institutional perspective. Organization Science, 13(6): 667-683.

Zaheer, A., \& Soda, G. 2009. Network evolution: The origins of structural holes. Administrative Science Quarterly, 54: 1-31.

Zhao, H., \& Lu, J. 2016. Contingent value of political capital in bank loan acquisition: Evidence from founder-controlled private enterprises in China. Journal of Business Venturing, 31: 153-174.

Publisher's note Springer Nature remains neutral with regard to jurisdictional claims in published maps and institutional affiliations.

Sonja Opper ( $\mathrm{PhD}$, University of Tubingen) is Professor of Global Strategy and Institutions at the Department of Management and Technology, Bocconi University. Her research is about how individual effort and local institutions contribute to some businesses being much more successful than others. In her current research she explores patterns of institutional change, the interplay between social network strategies and institutions, and social heuristics of strategic decisions. In her research she combines standard manager and company surveys, laboratory experiments and social network analysis. 